\title{
The Australian Public's Preferences Over Foreign Investment in Agriculture
}

\author{
James Laurenceson, ${ }^{1}$ Paul F. Burke and Edward Wei
}

\begin{abstract}
This paper estimates a model of how the Australian public's preferences over foreign investment in agriculture are determined. The results show that the attributes of foreign investment of greatest concern to the public are not the same as those used by the foreign investment approvals regime to flag proposals for scrutiny.
\end{abstract}

\section{Introduction}

In a 2012 poll, 63 per cent of Australians said that they were 'strongly against' '... the Australian government allowing foreign companies to buy Australian farmland to grow crops or farm livestock' (Lowy Institute 2012). A further 18 per cent said they were 'somewhat against', taking total disapproval to more than 80 per cent. Another poll in 2014 reported that 60 per cent of the public were against '... the Australian government allowing foreign companies to invest in agriculture', as compared with 38 per cent who were in favour (Lowy Institute 2014). Along with foreign investment in ports and airports, this was the lowest level of support across industry sectors, and compared with 58 per cent in favour for manufacturing and 55 per cent for the financial sector.

1 University of Technology Sydney, james.laurenceson@uts.edu.au. The authors would like to thank the editor, an anonymous referee, Peter Drysdale, Jane Goley, Zhangyue Zhou and Daniel Quiggin for comments received on an earlier version of this paper. Research assistance from Srishti Sethi is gratefully acknowledged. 
The basic rationale for Australia having a foreign-investment approvals regime is to provide the public with reassurance that proposed investments will bring community benefits. Yet, at least in the case of agriculture, the polling evidence presented above suggests that the regime is struggling to provide this reassurance. There could be a simple explanation, at least in part. The regime will only provide the public with reassurance if its design is consistent with how their preferences over foreign investment are determined. For example, the approvals regime makes extensive use of dollar-value thresholds. Currently, a proposed investment from a foreign, privately owned company in an Australian agribusiness is only scrutinised by the Foreign Investment Review Board (FIRB) if its value exceeds $\$ 252$ million. $^{2}$ However, the Australian government has announced its intention to reduce this threshold to $\$ 55$ million in December 2015 (FIRB 2015). ${ }^{3}$ In March 2015, the dollar-value threshold for foreign purchases of agricultural land was cut from a non-cumulative $\$ 252$ million to a cumulative $\$ 15$ million. ${ }^{4,5}$ Yet whether dollar-value thresholds act to provide the public with reassurance depends on whether it is the dollar value of foreign investment that is relevant to their preference formation. If preferences are insensitive to the dollar value, or if they are positively related - that is, the public prefers higher dollar-value foreign investments to lower dollar-value ones - it would be unsurprising if the regime failed to instil confidence. At the same time, the danger is that moves to lower dollar-value thresholds might add to the perceived cost of investing and make Australia's agricultural sector a less attractive destination as a result (Schlesinger 2015).

How public preferences over foreign investment in agriculture are determined is the question this paper seeks to answer. It does so using a choice modelling methodology. This approach invites members of the public to choose between a range of foreign investment scenarios that differ according to various attributes such as the dollar value, investor country of origin, and so on. In considering and trading off different investment attributes, those most relevant in determining preferences can be established.

The key finding is that there is a sizeable gap between the attributes of foreign investment that are of greatest concern to the public and the attributes the approvals regime uses to flag investment proposals for scrutiny. This divergence

\footnotetext{
2 Exceptions exist for foreign investment from New Zealand, the US and Chile, which have an approvals threshold of $\$ 1.094$ billion due to concessions embedded in long-standing Free Trade Agreements (FTAs) (FIRB 2015).

3 This lower threshold will not apply to investors from New Zealand, the US and Chile, who will continue to have a threshold of $\$ 1.094$ billion. It will, however, apply to countries that have recently negotiated FTAs with Australia, such as Japan, Korea and China (FIRB 2015).

4 A cumulative threshold means that if a foreign investor has previously bought agricultural land, the value of these past purchases will count towards the $\$ 15$ million threshold for new purchases.

5 Exceptions exist for investors from New Zealand, the US and Chile, who will have a \$1.094 billion threshold. Investors from Singapore and Thailand will have a threshold of \$50 million.
} 
may help to explain why the level of Australian public support for foreign investment in agriculture is limited. The most important investment attribute influencing how public preferences are determined is the foreign ownership share of an Australian agribusiness that a proposed investment will bring. Yet the foreign ownership share is not an attribute the approvals regime emphasises. Conversely, while the regime singles out higher dollar-value foreign investments for special attention, the results show that, everything else held constant, the public actually prefers higher dollar-value investments to lower dollar-value ones.

To the best of our knowledge, this paper is the first to consider how public preferences over foreign investment are determined, in Australia or elsewhere. It does, however, sit within a broader body of literature that seeks to provide critical reflection on the state of the foreign investment approvals regime. For example, Drysdale and Findlay (2009) and Drysdale (2011) considered whether investment from government-owned enterprises, particularly those from China, warranted special attention in the approvals process, while Mendelsohn and Fels (2014) examined whether the role and processes of the FIRB matched regulatory best practice.

\section{The regulation of foreign investment in agriculture in Australia}

The foundation of Australia's foreign investment approvals regime is the Foreign Acquisitions and Takeovers Act 1975 and the Foreign Acquisitions and Takeovers Regulation 1989. It was the 1975 Act that gave rise to the establishment of the FIRB in 1976. The job of the FIRB is to examine proposed foreign investments in Australia and make a recommendation to the Treasurer as to whether they are in the 'national interest'. The approvals regime is intended '... to reassure the Australian community that foreign investment was being monitored for the benefits that it brought to the Australian community' (Drysdale 2011: 56). The most recent, high-profile instance of proposed foreign investment in agriculture to fail this 'national interest' test was the sale of GrainCorp to American agribusiness Archer Daniels Midland in 2013.

The investment attributes used by the regime to determine which foreign investment proposals are scrutinised by the FIRB have evolved over time. Currently before Parliament is the Foreign Acquisition and Takeovers 
Legislation Amendment Bill 2015 which, amongst other things, is intended to enable the lowering of dollar-value screening thresholds for foreign investment in agriculture. ${ }^{6}$

Aside from dollar-value thresholds, the approvals regime also makes a sharp distinction between whether a proposal is coming from a foreign governmentowned or privately owned company. All investments from foreign governmentowned companies require FIRB scrutiny, irrespective of their dollar value. This distinction was introduced in 2009 and was widely perceived as a response to growing investment interest in Australia by Chinese government-owned companies (Mendelsohn and Fels 2014). Larem (2011) found that these regulations have contributed to perceptions by Chinese investors that Australia was a more difficult place to invest compared with other countries. Nonetheless, such a distinction in the approvals regime may still be worthwhile if it serves to build confidence amongst the Australian public that these proposals are being vetted for the community benefits they will bring. The problem is that it is not known whether the ownership type of a foreign investor is in fact an issue of concern to the public. The same is true for the dollar value of foreign investment.

Rather than the dollar value of foreign investment or the ownership type of a foreign investor, public preferences might instead be more importantly determined by other attributes. For example, amongst others, the public might be more concerned by the ownership share of an Australian agribusiness that a foreign company will acquire through an investment and/or the country of origin of the foreign investor.

\section{Methodology}

To investigate how public preferences are formed, this paper adopts a discrete choice experiment (DCE) approach, which has yet to be applied in this setting but has the potential to offer new insights. When investigating public preferences, traditional polling techniques ask respondents to consider one attribute of an issue without referring to, or trading these off against, other attributes. What this means is that respondents have no real incentive to provide clear direction on what attributes are most important in determining their preferences. A DCE provides a way to disentangle the impact that different attributes have on preferences.

\footnotetext{
6 While not directly related to the approvals process, also currently before Parliament is the Register of Foreign Ownership of Agricultural Land Bill 2015. The purpose of this legislation is to better understand the extent to which agricultural land is owned by foreign interests.
} 
DCEs have their roots in random utility theory and have a long history of being applied in transport, economics and marketing (for example, Ben-Akiva and Lerman 1985; Burke et al. 2010; Burke 2013; Louviere et al. 2000; Manski 1977; McFadden 1974; Train 2009). More recently, DCEs have been used in areas as diverse as education (Aubusson et al. 2014; Burke et al. 2015), health (Flynn et al. 2010; Lancsar et al. 2013) and climate change (Carson et al. 2010).

A DCE works by presenting survey respondents with a hypothetical scenario called 'a choice set'. Each choice set presents several alternatives: say, investment profile A, investment profile B and investment profile C. Respondents are asked to nominate which option they believe best matches a given criterion; in this instance, which investment profile option they most and least prefer. By asking respondents to select the most preferred and the least preferred profiles, a full ranking of the three investment profiles in each scenario can be collected. It also allows for testing of whether preference formation differs depending on if the investment choice is framed in terms of acceptance (most preferred) or objection (least preferred).

The investment alternatives are described by various attributes. In turn, each attribute has two or more levels. For example, one attribute of foreign investment could be country of origin. The levels for this attribute could be China, Japan, the US and the UK.

In this study, we considered seven attributes of foreign investment that might be expected to have an impact on public preferences. ${ }^{7}$ These comprised:

- Attribute 1: financial status of the Australian company. The Australian agribusiness receiving the foreign investment is a) on the verge of bankruptcy; or b) financially sound and looking to grow. That is, this attribute has two levels.

- Attribute 2: years in operation for the Australian company. The Australian agribusiness receiving the foreign investment has been in operation for a) five years; b) 10 years; c) 20 years; or d) 50 years. That is, this attribute has four levels.

- Attribute 3: ownership type of the foreign investor. The foreign company investing in the Australian agribusiness is a) government-owned; or b) privately owned.

7 As theory offers little guidance and there are no previous empirical studies that have considered how public preferences towards foreign investment are determined, these expectations are based on the actual criteria found in the approvals regime, as well as anecdotal evidence found in media sources that deal with the public response to instances of foreign investment. 
- Attribute 4: country of origin of foreign investor. The foreign company investing in the Australian agribusiness is from a) China; b) Japan; c) the UK; or d) the US.

- Attribute 5: dollar value of foreign investment. The amount of the foreign investment is a randomly drawn dollar value from 50 per cent below $\$ 55$ million to 50 per cent above \$55 million. Recall that from December 2015, \$55 million is the proposed dollar-value threshold for which foreign investment in an Australian agribusiness will be scrutinised by the FIRB.

- Attribute 6: local management control. After the foreign investment, the Australian agribusiness will have Australian citizens in a) a majority of the board and senior management positions; or b) a minority of the board and senior management positions.

- Attribute 7: foreign ownership share. After the foreign investment, the foreign company will own a randomly drawn percentage from 10 per cent to 100 per cent of the Australian agribusiness. The 10 per cent lower bound is chosen on the basis that an ownership share above 10 per cent is typically classified as being direct investment and will bring some degree of management control to the foreign investor.

Each respondent was given eight DCE scenarios to complete. An example of the DCE task is presented in Figure $1 .{ }^{8}$ Note that each scenario relates to brownfield investment (that is, a foreign investor acquiring equity in an existing company) rather than greenfield investment (that is, a foreign investor establishing a new company). It is the former that typically generates the greatest controversy in media commentary.

The levels for each of the attributes presented to respondents were determined using a completely randomised design in order to detect potential higherorder effects. For example, one specific higher-order interaction that may be of interest is China country of origin and government-owned ownership type. That is, the Australian public may display a particular sensitivity to a foreign investment proposal if it is from a Chinese, government-owned company. However, this interaction term proved statistically insignificant, as did nearly all other interactions. As a result, for brevity and parsimony what follows is a presentation of the main effects only models.

8 Other elements of the DCE, such as the introduction given to respondents, is available from the authors upon request. 


\section{Figure 1: Example of Discrete Choice Experiment (DCE)}

In this scenario, three cases of foreign investments in Australian agribusiness are shown below. Please examine the details of these investments and select the investment case that you agree with the MOST, and the investment case that you agree with the LEAST.

\begin{tabular}{|c|c|c|c|}
\hline Investment attributes & Investment A & Investment B & Investment C \\
\hline $\begin{array}{l}\text { 1. The Australian agribusiness } \\
\text { receiving the foreign investment is }\end{array}$ & $\begin{array}{l}\text { On the verge of } \\
\text { bankruptcy }\end{array}$ & $\begin{array}{l}\text { Financially sound } \\
\text { and looking } \\
\text { to grow }\end{array}$ & $\begin{array}{l}\text { Financially sound } \\
\text { and looking } \\
\text { to grow }\end{array}$ \\
\hline $\begin{array}{l}\text { 2. The Australian agribusiness } \\
\text { receiving the foreign investment } \\
\text { has been in operation for }\end{array}$ & 5 years & 50 years & 10 years \\
\hline $\begin{array}{l}\text { 3. The foreign company investing in } \\
\text { the Australian agribusiness is }\end{array}$ & $\begin{array}{l}\text { Government } \\
\text { owned }\end{array}$ & Privately owned & $\begin{array}{l}\text { Government } \\
\text { owned }\end{array}$ \\
\hline $\begin{array}{l}\text { 4. The foreign company investing in } \\
\text { the Australian agribusiness is from }\end{array}$ & China & Japan & US \\
\hline $\begin{array}{l}\text { 5. The amount of the foreign } \\
\text { investment is }\end{array}$ & \$30.3 million & \$69.3 million & $\$ 77.6$ million \\
\hline $\begin{array}{l}\text { 6. After the foreign investment, the } \\
\text { Australian agribusiness will have } \\
\text { Australian citizens in a }\end{array}$ & $\begin{array}{l}\text { minority of board } \\
\text { and senior } \\
\text { management } \\
\text { positions }\end{array}$ & $\begin{array}{l}\text { minority of board } \\
\text { and senior } \\
\text { management } \\
\text { positions }\end{array}$ & $\begin{array}{l}\text { minority of board } \\
\text { and senior } \\
\text { management } \\
\text { positions }\end{array}$ \\
\hline $\begin{array}{l}\text { 7. After the foreign investment, the } \\
\text { foreign company will own }\end{array}$ & $\begin{array}{l}94 \% \\
\text { of the Australian } \\
\text { agribusiness }\end{array}$ & $\begin{array}{l}28 \% \\
\text { of the Australian } \\
\text { agribusiness }\end{array}$ & $\begin{array}{l}88 \% \\
\text { of the Australian } \\
\text { agribusiness }\end{array}$ \\
\hline $\begin{array}{l}\text { Q1. Which investment do you agree with } \\
\text { the MOST? }\end{array}$ & $\square$ & $\square$ & $\square$ \\
\hline $\begin{array}{l}\text { Q2. Which investment do you agree with } \\
\text { the LEAST? }\end{array}$ & $\square$ & $\square$ & $\square$ \\
\hline
\end{tabular}

\section{Data}

The sample was drawn from the Australian panel of a global online data panel company proportional to key demographic statistics in census data from the Australian Bureau of Statistics (ABS). All respondents were eligible to vote in the next federal election. In total, data were collected from 1,523 respondents. This means that model estimation was conducted on the basis of preferences exhibited over $1,523 \times 8=12,184$ foreign investment scenarios.

Summary statistics for the sample relating to sex, age, location, ethnic background, household income and education are shown in Table 1. The proportion of the sample holding a Bachelor degree or higher is 42.1 per cent. This compares with the average of the working-age population of 27.9 per cent (ABS 2012). The difference mostly likely arises from the opt-in nature of online data panels. That is, to participate in such a survey, online know-how and savvy is required and this is likely to be positively correlated 
with educational attainment. Fortunately, there is little reason to think that this difference will bias our results. The sample still comprises 57.9 per cent, or 592 respondents, who do not have a Bachelor degree qualification, including 10.9 per cent who did not finish Year 12. These varying levels of educational attainment can be interacted with investment attributes to examine whether there are any statistically significant differences in how preferences are determined. These results are discussed below.

Table 1: Summary statistics of respondents $(n=1,523)$

\begin{tabular}{|l|r|}
\hline Sex & Percentage \\
\hline Male & 50 \\
\hline Female & 50 \\
\hline
\end{tabular}

\begin{tabular}{|l|r|}
\hline Born in Australia & Percentage \\
\hline Yes & 79.8 \\
\hline No & 20.2 \\
\hline
\end{tabular}

\begin{tabular}{|l|r|}
\hline Age & Percentage \\
\hline Up to 24 & 12.3 \\
\hline $25-34$ & 20.9 \\
\hline $35-44$ & 19.8 \\
\hline $45-54$ & 19.8 \\
\hline $55-64$ & 15.1 \\
\hline $65-74$ & 8.3 \\
\hline $75+$ & 3.7 \\
\hline
\end{tabular}

\begin{tabular}{|l|r|}
\hline Language at home & Percentage \\
\hline English only & 86.4 \\
\hline Other languages & 13.6 \\
\hline
\end{tabular}

\begin{tabular}{|l|r|}
\hline Location & Percentage \\
\hline NSW & 33.3 \\
\hline VIC & 24.8 \\
\hline QLD & 19.5 \\
\hline SA & 7.6 \\
\hline WA & 10.0 \\
\hline ACT & 1.6 \\
\hline TAS & 2.4 \\
\hline NT & 1.0 \\
\hline
\end{tabular}

\begin{tabular}{|l|r|}
\hline Annual household income & Percentage \\
\hline Below \$52K & 31.3 \\
\hline \$52K-104K & 32.4 \\
\hline \$104K-156K & 15.2 \\
\hline \$156K-208K & 4.7 \\
\hline \$208K + & 3.2 \\
\hline Prefer not to answer & 13.1 \\
\hline
\end{tabular}

\begin{tabular}{|l|r|}
\hline Highest non-school qualification & Percentage \\
\hline Bachelor degree or higher & 42.1 \\
\hline University/TAFE diploma or certificate & 37.0 \\
\hline None of the above & 20.9 \\
\hline
\end{tabular}

\section{Results}

A multinomial choice model (MNL) was used to analyse data collected from the 1,523 respondents. Three models were estimated based on the most preferred investment profile, the least preferred investment profile and an aggregation of the two sets of responses (that is, a combined model). The results are presented in Table 2. 


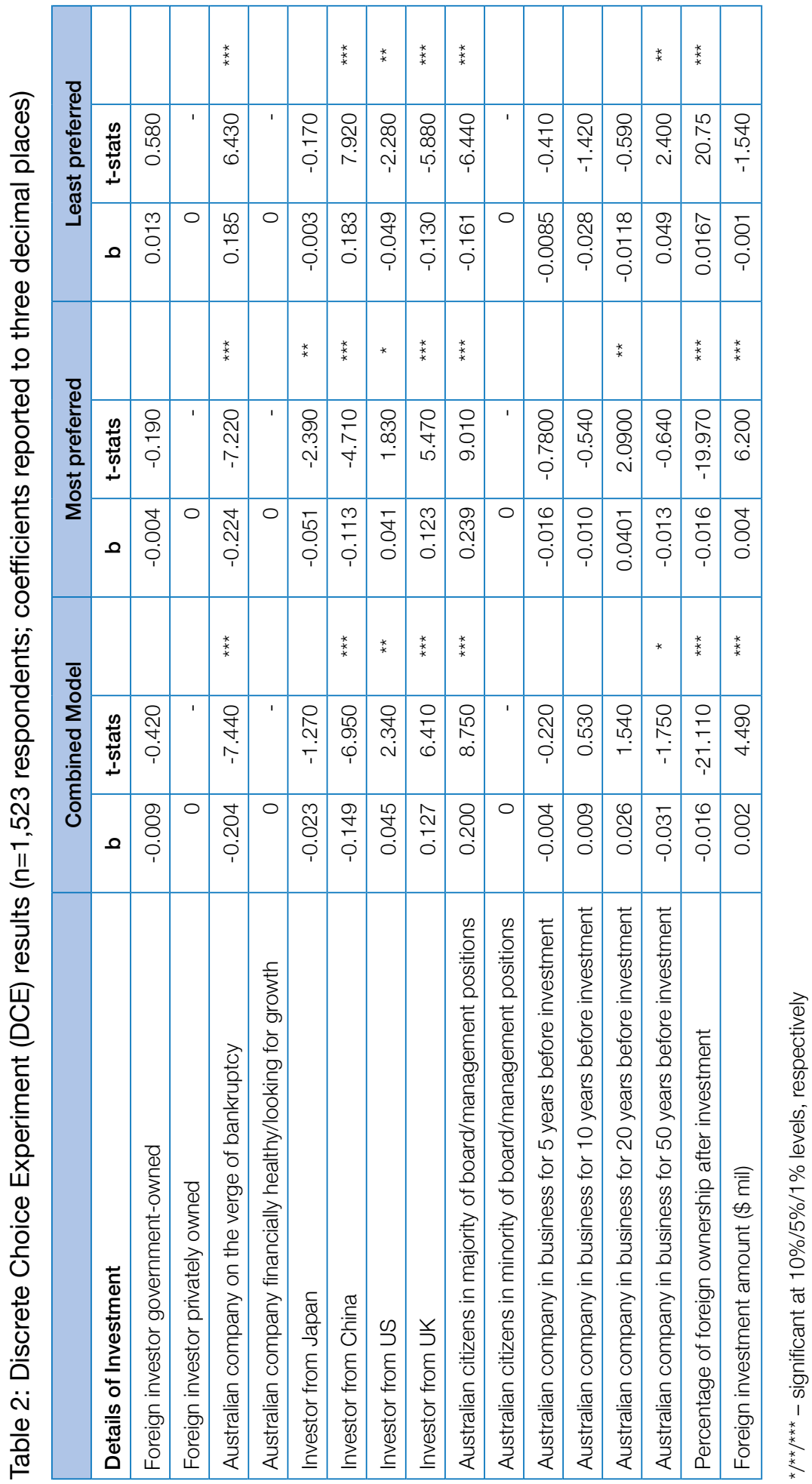


Each variable was included and excluded from the combined model to assess its statistical significance in improving model fit. The log-likelihoods between the final and each restricted model can be compared against a chi-square distribution, or equivalently the AIC and BIC criterion. These comparisons allow the impact of each variable to be compared by taking into account the difference in degrees of freedom associated with any one set of variables. The attribute most responsible for improvements in model fit was the foreign ownership share. This was followed by the financial status of the Australian company, the extent of local management control, the country of origin of the foreign investor, the dollar value of foreign investment and the number of years the Australian agribusiness had been in operation. The only variable not contributing to a statistically significant improvement in model fit was the ownership type of the foreign investor.

We now discuss the findings for each variable in greater detail in order of their significance.

\section{Foreign ownership share (attribute 7)}

Based on the combined model, the most statistically significant attribute of foreign investment determining public preferences is the foreign ownership share. The coefficient is negative. This means that, everything else held constant (for example, the investment is from the same country, and so on), as the share of foreign ownership increases, the public prefers the investment less. Tests also reveal the relationship between the foreign ownership share and preferences is linear.

Beyond sign and statistical significance, coefficient values can also be interpreted by looking at the marginal changes in outcomes they imply using representative values. By way of illustration, consider foreign ownership shares of 10 per cent (the lower bound) compared with 100 per cent (the upper bound). The coefficient of -0.016 implies that if the public is choosing between these two investment profiles, the probability that the one featuring 10 per cent foreign ownership will be preferred to one featuring 100 per cent foreign ownership is 81 per cent. ${ }^{9}$

What makes this finding potentially instructive for policy formation is that while the foreign ownership share is the attribute of greatest concern to the public, it does not feature prominently in the foreign investment approvals regime. Instead, as noted earlier, the regime focuses on the dollar value of foreign investment. Sometimes the FIRB may include a condition that relates to the foreign ownership share. For example, in 2012 it approved Shandong Ruyi,

9 The preference associated with foreign ownership at only 10 per cent compared with 100 per cent is based on the function $\left(\exp ^{\left(10^{*}-0.0164\right)} /\left(\exp ^{\left(10^{*}-0.0164\right)}+\exp ^{\left(100^{*}-0.0164\right)}\right)\right)$, while holding everything else constant. 
a Chinese-Japanese investor, to purchase an 80 per cent share of Cubbie Station, a Queensland cotton and irrigation property. The remaining 20 per cent stake was bought by an Australian company, Lempriere Group. The FIRB's approval required that Shandong Ruyi reduce its holding to 51 per cent within three years. However, if Shandong Ruyi's purchase had been less than the \$252 million value threshold specified in the approvals regime, the foreign ownership share would have been irrelevant as the deal would not have required scrutiny by FIRB in the first place.

\section{Financial status of the Australian company (attribute 1)}

The second-most significant determinant of preferences was the financial status of the Australian agribusiness. The coefficient was negative, implying that the public prefer a foreign investment less when it is in an Australian agribusiness on the verge of bankruptcy. A possible interpretation is that the public fears such investment might result in a loss of domestic assets at 'fire sale' prices.

\section{Local management control (attribute 6)}

The next-most significant determinant of preferences was whether foreign investment would see a majority or a minority of board and senior management positions being held by Australian citizens. The coefficient is positive, meaning that the public prefers a foreign investment more if Australian citizens occupy a majority of board and senior management positions.

\section{Country of origin of the foreign investor (attribute 4)}

The evidence for the country of origin of the foreign investor having a significant impact on preferences was mixed. On the one hand, the coefficient for the UK was positive and statistically significant. That is, if foreign investment is from the UK, the public prefer it more. In contrast, the coefficient for China was negative and statistically significant, meaning the public prefer it less. The coefficients for the US and Japan were positive and negative respectively, but only marginally statistically significant or insignificant.

That said, it is useful to read this finding in conjunction with those above. In particular, while investment from China was preferred less than investment from the UK, this preference appears readily moderated. For example, the coefficient values imply that, everything else held constant, the public would be indifferent between an investment profile featuring investment from the UK that resulted in 70 per cent foreign ownership, and another that featured investment from China that resulted in 53 per cent foreign ownership. Or put another way, the public would prefer an investment profile that featured 
investment from China and with Australian citizens in a majority of board and senior management positions, compared to investments from the US or Japan with Australian citizens in a minority.

Aside from the combined model, the results in Table 2 also report on significant effects relating to the decision by respondents to indicate their most preferred investment option and, separately, their least preferred option. In most instances, the effects across these models are not significantly different. However, this is not the case with respect to investor country of origin. Specifically, the results indicate that the opposition to investment from China is significantly stronger when the choice is framed in terms of objection (least preferred) relative to acceptance (most preferred).

\section{Dollar value of foreign investment (attribute 5)}

The coefficient to the dollar value of foreign investment is positive, implying that as the dollar value increases the public prefers it more. Model tests reveal the impact of the dollar value of foreign investment on preferences is linear. This result is not inconsistent with the finding that the public prefers a lower foreign ownership share: the public may value large capital contributions while at the same time preferring a greater proportion of the equity in a joint venture to be held by local interests.

This result stands out for two reasons. First, the dollar value of foreign investment is shown to be an attribute of foreign investment of only modest statistical significance in determining public preferences. Yet in the approvals regime it is the single most important attribute of investment used to flag whether proposals are scrutinised by the FIRB. Second, the coefficient is positive, which means that recent moves in the approvals regime to reduce dollar-value screening thresholds are unlikely to increase public confidence in the community benefits of foreign investment. This is because the public actually prefers higher dollarvalue investments to lower dollar-value ones.

\section{Years in operation (attribute 2)}

The years that an Australian agribusiness has been in operation generally has a statistically insignificant impact on preferences. The one exception was if the company had been in operation for 50 years. In this case, the public prefers the foreign investment less. This may indicate that the public has some reluctance seeing foreign investment in Australian companies that might be regarded as iconic. 


\section{Ownership type (attribute 3)}

Whether investment was coming from a foreign company that was governmentowned or privately owned had a statistically insignificant impact on preferences.

Once again this points to a gap between the attributes of foreign investment that are of greatest concern to the public and the attributes the approvals regime uses to flag proposals for scrutiny by the FIRB. As noted earlier, all investment from foreign government-owned companies require FIRB screening, irrespective of dollar value. What this result means is that the regime is likely to add to perceptions by investors such as Chinese government-owned companies that the approvals process is restrictive, while at the same time not providing the public with greater confidence in the community benefits.

\section{Socio-demographic heterogeneity in preference formation}

The analysis so far has considered how preferences are formed by the average member of the Australian public. The question arises, however, whether different socio-demographic groups might form their preferences differently: for example, city dwellers versus non-metropolitan residents; men versus women; and so on. The most straightforward way to consider these possibilities is to test whether there are any statistically significant differences in interactions between socio-demographic characteristics and foreign investment attributes. In a choice modelling exercise, socio-demographic characteristics can be introduced into the estimation procedure using effects coding. This is akin to a dummy variable approach in regular regression. The difference is that instead of modelling, say, sex using zero and one, the coding takes the form of one and minus one. For attributes with more than two levels, one level is used as the base and is the negative sum of the other levels. In the dummy variable approach, the reference level is coded as zero.

Generally, few differences were found. For example, no differences were revealed with respect to education levels or whether respondents were living in cities versus non-metropolitan areas. However, age and sex did show up differences with respect to increased levels of foreign ownership, reduced levels of local management control and China as a source country of investment. Specifically, older persons and females were found to be significantly more sensitive to investment options along these lines. ${ }^{10}$

10 Specific results with respect to the interaction between socio-demographic characteristics and foreign investment attributes are available from the authors upon request. 


\section{Conclusion}

This paper began by observing that the Australian public has reservations over foreign investment in agriculture. A model of how public preferences over foreign investment are determined was then estimated. The results highlight one possible reason why public support may be limited. There is a gap between the attributes of foreign investment that are of greatest concern to the public and the attributes used by the approvals regime to flag proposals for scrutiny. Morever, recent changes to the approvals regime, such as lowering the dollarvalue threshold that triggers FIRB review and instigating a different approvals process for proposals from foreign government-owned investors, fail to close the gap. This divergence may have implications for how the Australian government forms policy in this domain.

Another implication of the findings is that they may provide insight for foreign investors and their Australian partners into how cooperation can be structured to gain better public acceptance. For example, while investment proposals from China do suffer from a negative country-of-origin effect, this effect is readily moderated by other attributes of the investment, such as placing Australian citizens in a majority of the board and senior management positions. A survey of Chinese investors in Australia in 2014 found that negative media coverage was one of the key challenges they faced. Only 16 per cent 'agreed' with the statement that 'Australian media are supportive of Chinese investment'. None 'strongly agreed' (KPMG 2014). To the extent that media coverage both reflects and informs public preferences, the findings of this study could act to overcome this barrier.

Whether the public preferences over foreign investment modelled in this paper also hold for proposals outside of the agribusiness sector in Australia, or in other countries, remains to be verified. Nonetheless, the methodology adopted in this paper could readily be used to answer these questions.

\section{References}

Aubusson, P., Burke, P., Schuck, S., Kearney, M. and Frischknecht, B. 2014, 'Teachers Choosing Rich Tasks The Moderating Impact of Technology on Student Learning, Enjoyment, and Preparation', Educational Researcher 43(5): 219-29. 
Australian Bureau of Statistics 2012, 'Education differences between men and women' in Australian Social Trends, September 2012 (ABS catalogue no. 4102.0). Available at: www.abs.gov.au/AUSSTATS/abs@.nsf/Lookup/4102.0 Main+Features20Sep+2012.

Ben-Akiva, M. and Lerman, S.R. 1985, Discrete choice analysis: Theory and application to travel demand, MIT Press, Cambridge, MA.

Burke, P.F., Aubusson, P.J., Schuck, S.R., Buchanan, J.D. and Prescott, A.E. 2015, 'How do early career teachers value different types of support? A scale-adjusted latent class choice model', Teaching and Teacher Education 47: $241-53$.

Burke, Paul F., Burton, C., Huybers, T., Islam, T., Louviere, J.J. and Wise, C. 2010, 'The Scale-Adjusted Latent Class Model: Application to Museum Visitation', Tourism Analysis 15(2): 147-65.

Burke, P.F. 2013. 'Seeking Simplicity in Complexity: The Relative Value of Ease of Use (EOU)-Based Product Differentiation', Journal of Product Innovation Management 30(6): 1227-41.

Carson, R.T., Louviere, J.J. and Wei, E. 2010, 'Alternative Australian climate change plans: The public's views', Energy Policy 38(2): 902-11.

Drysdale, P. and Findlay, C. 2009, 'Chinese foreign direct investment in Australia: policy issues for the resource sector', China Economic Journal 2(2): 133-58.

Drysdale, P. 2011, 'A new look at Chinese FDI in Australia', China \& World Economy 19(4): 54-73.

Flynn, T.N., Louviere, J., Peters, T.J. and Coast, J. 2010, 'Using discrete choice experiments to understand preferences for quality of life. Variance-scale heterogeneity matters', Social Science \& Medicine 70(12): 1957-65.

Foreign Investment Review Board(FIRB) 2015, Strengthening the foreign investment framework. Available at: www.firb.gov.au/content/strengthening_FIF.asp.

KPMG and Sydney University 2014, Demystifying Chinese investment: Chinese investors in Australia survey. Available at: www.kpmg.com/AU/ en/IssuesAndInsights/ArticlesPublications/china-insights/Documents/ demystifying-chinese-investment-in-australia-survey-nov-2014.pdf.

Lancsar, E., Louviere, J., Donaldson, C., Currie, G. and Burgess, L. 2013, 'Best worst discrete choice experiments in health: methods and an application', Social Science \& Medicine 76: 74-82. 
Larum, J. 2011, Chinese perspectives on investing in Australia. Lowy Institute for International Policy. Available at: www.lowyinstitute.org/files/pubfiles/ Larum,_Chinese_perspectives_web.pdf.

Louviere, J.J., Hensher, D.A. and Swait, J.D. 2000, Stated choice methods Analysis and application, Cambridge University Press, Cambridge, UK.

Lowy Institute 2012, The Lowy Institute Poll 2012. Available at: www.lowy institute.org/publications/lowy-institute-poll-2012-public-opinion-andforeign-policy.

_ 2014, The Lowy Institute Poll 2014. Available at: www.lowyinstitute.org/ publications/lowy-institute-poll-2014.

Manski, C. 1977, 'The structure of random utility models', Theory and Decision 8(3): 229-54.

McFadden, D. 1974, 'Conditional logit analysis of qualitative choice behavior', in P. Zarembka (ed.), Frontiers of economics, Academic Press, New York.

Mendelsohn, R. and Fels, A. 2014, 'Australia's foreign investment review board and the regulation of Chinese investment', China Economic Journal 7(1): 59-83.

Schlesinger, L. 2015, 'FIRB crackdown makes Australia high-cost, says Austrade', Australian Financial Review, 11 June.

Train, K.E. 2009, Discrete choice methods with simulation, 2nd edn, Cambridge University Press, Cambridge, UK. 
This text is taken from Agenda, Volume 22 - Number 1, 2015, edited by William Coleman, published 2015 by ANU Press, The Australian National University, Canberra, Australia. 